\title{
DIFFERENTIATION BETWEEN SOME TAXA OF Brassica SIMILAR IN SEED SHAPE AND PLANT ORGANS AT EARLY GROWTH STAGES
}

\author{
( Received: 16.8. 2008 )
}

\author{
By \\ A. Z. Sabh and M. H. A. Abou-Bakr \\ Department of Agricultural Botany, Faculty of Agriculture, Cairo University
}

\begin{abstract}
This investigation was carried out at the greenhouse of the Department of Agricultural Botany, Faculty of Agriculture, Cairo University, during 2006 season to differentiate between three taxa of Brassica; namely, B. oleracea var. botrytis (Cauliflower), B. oleracea var. italica (Broccoli) and B. oleracea var. capitata (Cabbage), being similar at early stages of growth as well as seed shape.

The results showed that, there were clear differences between the three taxa as some macroand micro-morphological characters were used such as; seed colour (light brown to dark grey in Cauliflower, red to light red in Broccoli, and light brown to light grey in Cabbage), hilum colour (dark grey in Cauliflower, light brown in Broccoli, and light grey in Cabbage), seed surface sculpture by using SEM (ruminate-pusticulate in Cauliflower, ruminate with weak reticulate in Broccoli, and reticulate-rugose in Cabbage), leaf lamina margin (crenatus in Cauliflower, erosus in Broccoli, and serratus in Cabbage), leaf lamina base (inaequilaterus in Cauliflower, truncates in Broccoli and breve angustatus in Cabbage).

Meanwhile, the anatomical differences of leaf lamina, petiole, stem and root were less clear between the three investigated taxa at the early stages of growth (up to 45 days). Thus, the anatomical studies may be more useful at older plant stages to find out these differences.
\end{abstract}

Key words: anatomy, brassica, broccoli, cabbage, cauliflower, morphology, seed, seedling, SEM.

\section{INTRODUCTION}

The genus Brassica belongs to the family Brassicaceae (Cruciferae) which is commonly known as the mustard family. The family consists of about 375 genra and 3200 species, and includes crops, condiments, ornamentals, and many weeds. Brassica contains about 100 species, including cabbage, cauliflower, broccoli, brussels sprouts, various mustards and weeds (Willis, 1973).

Brassicaceae plants are found mainly in the North Temperate zone, particularly in the Mediterranean region. Plants are annual, biennial or perennial, herbs or very seldom shrubs. The family plants are rich in vitamin $\mathrm{C}$, and sulphur compounds which give their pungent odour. Vegetables; such as broccoli and cauliflower are known to be anticancer foods (Cronquist, 1981, and Jones and Luchsinger, 1987). Brassica species have a great economic significance in agriculture as oilseed, now being the world's third most important source (Downey,1990, and Kumar,1995).

There are six genetically related species, B. nigra , B. rapa, B. napus, B. carinata, $B . j u n c e a$, and $B$. oleracea, which includes; $B$. oleracea var. capitata L.(Cabbage), $B$. oleracea var botrytis L.(Cauliflower) and $B$. oleracea var. italica L.(Broccoli) ( Robbelen et al.,1989).

The morphology of seed surface has been the subject of many studies. Karcz et al. (2005) investigated the morphology of seed surfaces by using SEM and found that, the seed coat varied in shape and size of the epidermal cells of the testa and also the structure of the outer periclinal and anticlinal cell walls.

Other recent studies of different seed coat characters employed SEM. Koul et al., (2000), gave detailed descriptions of seed 
morphology in 44 species of the Brassicineae, Raphaninae and Moricandiinae, and elucidated the phylogenetic relationships between them. Recently, Zeng et al. (2004) examined testa topographic patterns during seed development in the cultivated forms of these species. Vaughan and Whitehouse (1971) studied the macro- and micromorphological characters of approximately 90 genera and 200 species of Brassicaceae with special interest in the relationship between structure and existing taxonomy. Tantawy et al.(2004) investigated the seed exomorphic characters of 34 taxa of Brassicaceae representing 22 genera and 30 species by using LM and SEM. They concluded that the seed exomorphic characters, are diagnostic at the genetic and specific level; seed shape, dimensions, colour of epidermal cells, seed surface sculpture and aspects of anticlinal and periclinal walls.

The present study was conducted to differentiate between three taxa of Brassica being similar at early stages of growth as well as their seed shape.

\section{MATERIALS AND METHODS}

The present research was carried out at the greenhouse of the Department of Agricultural Botany, Faculty of Agriculture, Cairo University, to differentiate between three taxa belonging to the genus Brassica of Brassicaceae ; B. oleracea var. capitata L.(Cabbage), B. oleracea var. botrytis L.(Cauliflower) and B. oleracea var. italica L.(Broccoli). Seeds of the three taxa were obtained from the Department of Vegetable Researchs, Agricultural Research Center, Dokki, Giza, Egypt.

Pots, $30 \mathrm{~cm}$ in diameter were filled with sand and peatmoss, at the rate of 1:3. Five seeds/pot were sown on 15 October 2006 and 5 pots/species were assigned for the study of the following characters:

1) Description of the morphology of the first vegetative leaf (30 day old).

2) Anatomical studies: a) Samples $1 \mathrm{~cm}$ long, were taken from the middle portion of the tap root at the age of 10 days to get intact roots and the apical internodes at the age of 30 days. b) Petiole and lamina at the two ages of 30 and 45 days.

All anatomical specimens were killed and fixed in F.A.A. $(10 \mathrm{ml}$ Formalin-5ml Acetic acid- $85 \mathrm{ml}$ Alcohol $70 \%$ ), washed in $50 \%$ ethyl alcohol, dehydrated in normal butyl alcohol series and embedded in paraffin wax $\left(55^{\circ} \mathrm{C}\right.$ mp.), (Sass, 1958). Cross sections $20 \mu \mathrm{m}$ thick, were cut, using rotary microtome , stained by crystal violet /erythrosin combination and mounted in Canada balsam (Jackson, 1926). Sections were examined and counts and measurements of different tissues were calculated. Photomicrographs were also taken.

Mature seeds of the studied taxa were used for SEM examination, at various magnifications to elucidate seed morphological features. Magnification power ranged between X25 to X1300, depending on size of the seeds to show the finest details of seed surface sculptures. Terms given by Murley (1951) and modified by Stearn (1983) were used.

Seed dimensions were measured by using a micrometer eyepiece, and averages of 10 readings for seed length and width were calculated. Morphological features of different seeds were described using a binocular stereomicroscope.

The detailed surface scan features were examined using a JEOL-JSM-T 100 Model Scanning Electron Microscope and SEMmicrographs were taken at the Central Laboratory, National Research Center (NRC), Dokki, Giza, Egypt.

\section{RESULTS AND DISCUSSION 3.1. Plant Morphology 3.1.1.Morphology of lamina and seed:}

Shape and morphology characters of leaf lamina, seed and seed measurements of the three studied taxa are presented in Table (1) and Figs. (1 and 2).

The lamina shape is ovatum in cauliflower, obtuse crenatum in broccoli and oval in cabbage. On the other hand, leaf margin is crenatous, erosus and serratus, for cauliflower, broccoli and cabbage plants; respectively. For the lamina tip and base, it was obtusus and inaequilaterus, in cauliflower; round and truncatus in broccoli; and obtuse and breve angustatus in cabbage.

Concerning seed characters and measurements, the colours of the seeds are light brown to dark grey, for cauliflower; red to light red, for broccoli; and light brown to light grey in cabbage. Averages of measurements of seed length and width are 1.9 and $1.7 \mathrm{~mm}, 1.9$ and $1.7 \mathrm{~mm}$; and 2.0 


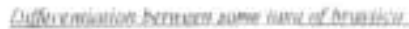

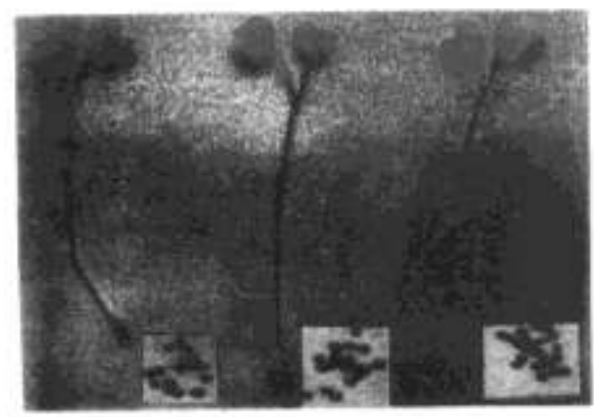

A

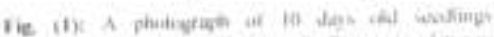

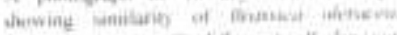

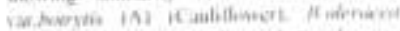

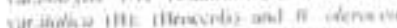

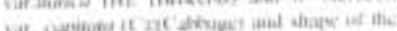

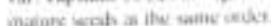

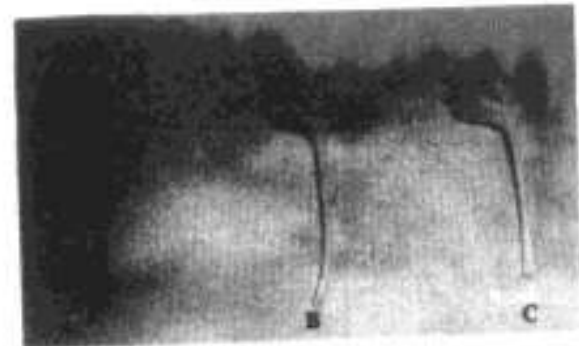

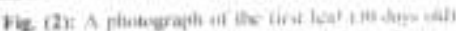

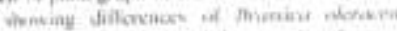
car hom

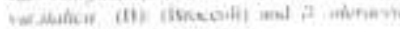

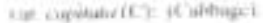

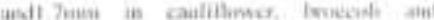

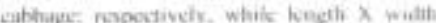

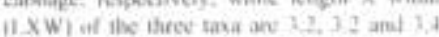

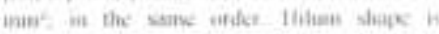
vimitar in the three lasa, while ife culours an dart yer in caeliflower. light bown in

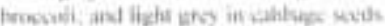
1.2. Mani sastean

1.2. The ieaf lamina

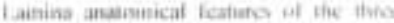

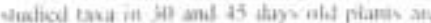

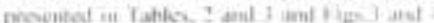
iA, it and $($ ?

\subsubsection{Caulifower}

At the age of 30 dayn, the upger vurfuce if the rgidrib region (Fig. 3A) is eoncave, white the lower one is convec, and the Ihickneas of the upper and the lower epidernis reconden 15.3 and $12.4 \mu \mathrm{m}$, resnoctively (Table, 2). The menophyli tissuac (214.6 fm thich) consist of 2.j layers of palisade tissue (129.8 um thick) The spoagy insace (103.8 yim thid) ।

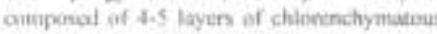
odik. lociuby arranged with many wide

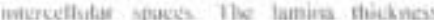

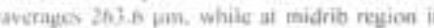

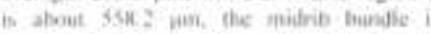
siebaty nousded in shape with a leages and

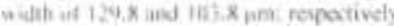

The taniena in 45 day eis planta (Table. )

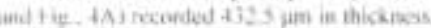
anid its loper and lower enideneis ane 41 . and ZX.A pas, respectivsily. The mesophyl

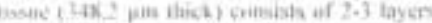

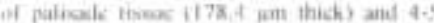

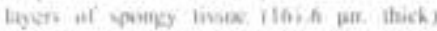
Thicknces if meitrik regiens is $42 \times .7$ ym and

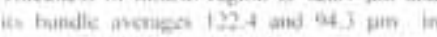
kongth and wilat, ropectively

\subsubsection{Hericsul:}

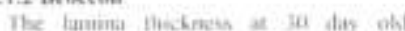
avoraess 196,7 yen ond the upper and the

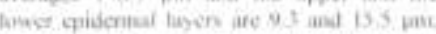
thes: rospestiesh. The mesopteyll tosus

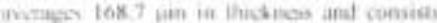

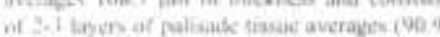

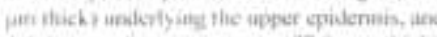
is layere of quingy nowe $(77.4$ na thich umely arranesil with suany wide indercetiules

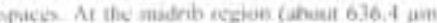

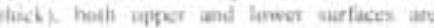
causc. The mainit bundfe is ncarly spiare in thasc and with a hangeh wad widih of ize.n

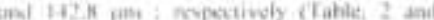
ty.t. 3th!

Ai the alpe on 45 dityo I Table, 3 and Fig.

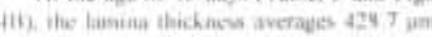

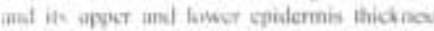

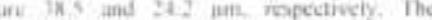

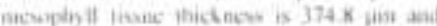

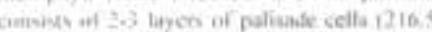
ine thick) and is layen of speirgy cell 115? 2 yai thicht the anitrib recieat reconded

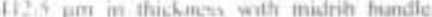

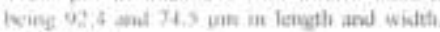
woratinsty 
Table (1): Morphological descriptions of the leaf and seed of the three studied taxa; Cauliflower, Broccoli and Cabbage.

\begin{tabular}{|c|c|c|c|}
\hline $\begin{array}{ll}\text { Characters } & \text { Taxa } \\
\end{array}$ & Cauliflower & Broccoli & Cabbage \\
\hline Leaf lamina: Shape & ovatum & $\begin{array}{c}\text { obtuse } \\
\text { crenatum }\end{array}$ & oval \\
\hline Margin & crenatus & erosus & serratus \\
\hline Tip & obtusus & round & obtuse \\
\hline Base & inaequilaterus & truncates & $\begin{array}{c}\text { breve } \\
\text { angustatus }\end{array}$ \\
\hline Seed: Colour & $\begin{array}{c}\text { light brown to } \\
\text { dark grey }\end{array}$ & red to light red & $\begin{array}{l}\text { light brown to } \\
\text { light grey }\end{array}$ \\
\hline Length (L) mm & 1.9 & 1.9 & 2.0 \\
\hline Width (W) $\mathrm{mm}$ & 1.7 & 1.7 & 1.7 \\
\hline $\mathrm{LX} \mathrm{W} \quad \mathrm{mm}^{2}$ & 3.2 & 3.2 & 3.4 \\
\hline Hilum: & semi-lunar & semi-lunar & semi-lunar \\
\hline Colour & dark grey & light brown & light grey \\
\hline
\end{tabular}

Table (2): Measurements of certain microscopical features in transverse sections of lamina of $\mathbf{3 0}$ day old plants of the three studied taxa; Cauliflower, Broccoli and Cabbage (Averages of 10 readings).

\begin{tabular}{|l|c|c|c|}
\hline \multicolumn{1}{|c|}{ Taxa } & Cauliflower & Broccoli & Cabbage \\
Characters & & & \\
\hline Upper epidermis thickness $(\mu \mathrm{m})$ & & 9.3 & 24.8 \\
\hline Lower epidermis thickness $(\mu \mathrm{m})$ & 12.4 & 15.5 & 15.5 \\
\hline Lamina thickness $(\mu \mathrm{m})$ & 263.6 & 196.7 & 273.8 \\
\hline Mesophyll thickness $(\mu \mathrm{m})$ & 234.6 & 168.7 & 233.8 \\
\hline Palisade tissue thickness $(\mu \mathrm{m})$ & 129.8 & 90.9 & 129.8 \\
\hline No. of palisade layers & $2-3$ & $2-3$ & $2-3$ \\
\hline Spongy tissue thickness $(\mu \mathrm{m})$ & 103.8 & 77.9 & 103.8 \\
\hline No. of spongy layers & $4-5$ & $4-5$ & $4-5$ \\
\hline Thickness of midrib region $(\mu \mathrm{m})$ & 558.2 & 363.4 & 610.1 \\
\hline Length of midrib bundle $(\mu \mathrm{m})$ & 129.8 & 129.8 & 142.8 \\
\hline Width of midrib bundle $(\mu \mathrm{m})$ & 103.8 & 142.8 & 220.7 \\
\hline
\end{tabular}

Table (3): Measurements of certain microscopical features in transverse sections of lamina of $\mathbf{4 5}$ day old plants of the three studied taxa; Cauliflower, Broccoli and Cabbage (Averages of 10 readings ).

\begin{tabular}{|l|c|c|c|}
\hline \multicolumn{1}{r|}{ Taxa } & Cauliflower & Broccoli & Cabbage \\
\hline Characters & & & \\
\hline Lower epidermis thickness $(\mu \mathrm{m})$ & 41.5 & 38.5 & 42.2 \\
\hline Lamina thickness $(\mu \mathrm{m})$ & 28.4 & 24.2 & 36.5 \\
\hline Mesophyll thickness $(\mu \mathrm{m})$ & 432.5 & 428.7 & 464.3 \\
\hline Palisade tissue thickness $(\mu \mathrm{m})$ & 348.2 & 374.8 & 378.6 \\
\hline No. of palisade layers & 178.4 & 216.5 & 190.8 \\
\hline Spongy tissue thickness $(\mu \mathrm{m})$ & $2-3$ & $2-3$ & $2-3$ \\
\hline No. of spongy layers & 161.6 & 157.2 & 176.4 \\
\hline Thickness of midrib region $(\mu \mathrm{m})$ & $4-5$ & $4-5$ & $4-5$ \\
\hline Length of midrib bundle $(\mu \mathrm{m})$ & 428.7 & 442.5 & 432.5 \\
\hline Width of midrib bundle $(\mu \mathrm{m})$ & 122.4 & 92.4 & 88.5 \\
\hline
\end{tabular}




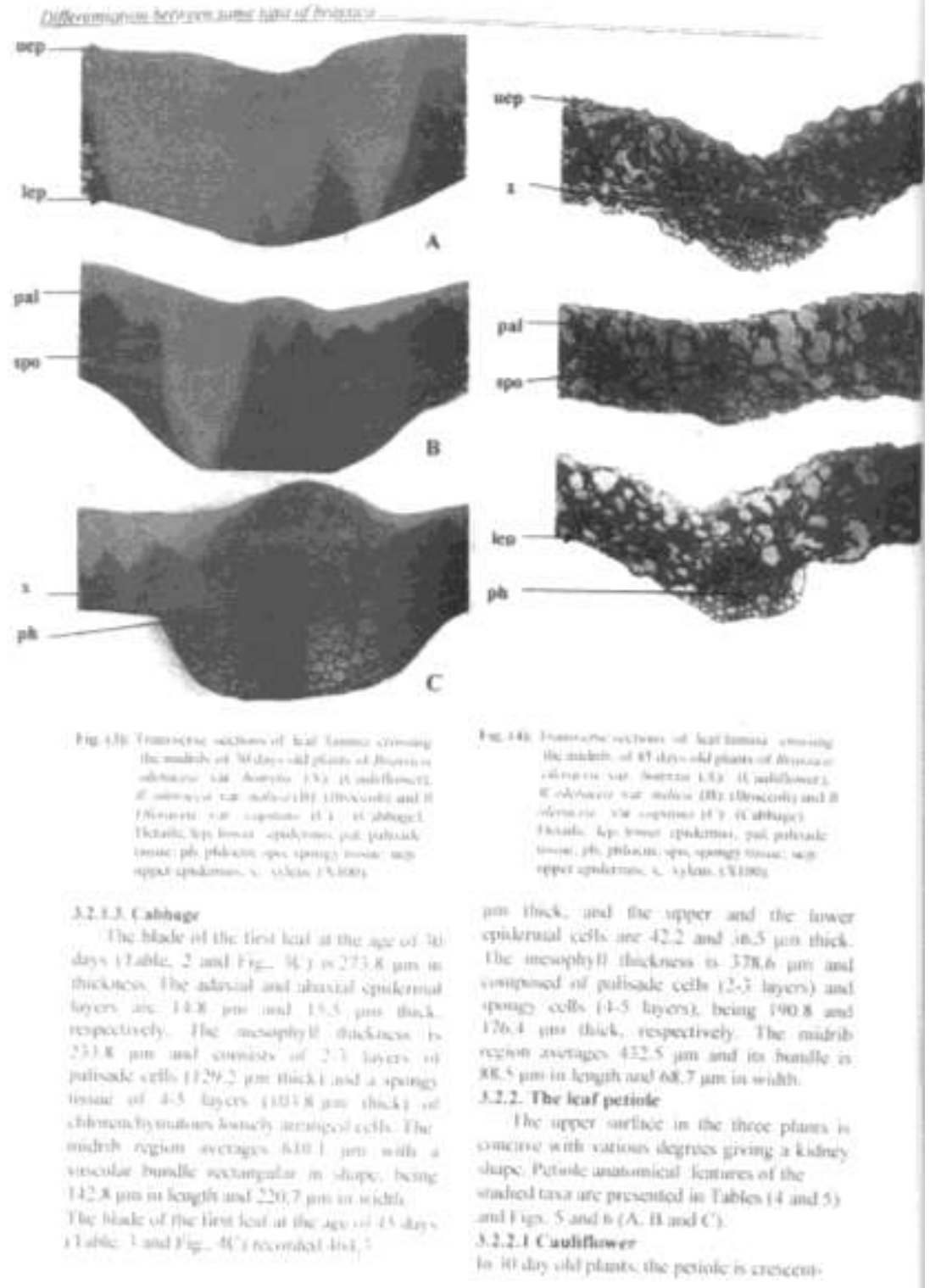


shaped $780.0 \mu \mathrm{m}$ long and $1363.0 \mu \mathrm{m}$ in width (Table, 4 and Fig. 5A), with upper epidermis, $15.5 \mu \mathrm{m}$ thick, and a lower epidermis $9.3 \mu \mathrm{m}$ thick, respectively. There are 3 large vascular bundles in the middle embedded in parenchyma, and the largest measured 162.3 and $227.5 \mu \mathrm{m}$ in length and width, respectively.

At the age of 45 days, (Table, 5 and Fig., 6A) the petiole of the first leaf recorded 694.8 $\mu \mathrm{m}$ in length and $487.3 \mu \mathrm{m}$ in width. The upper and the lower epidermis are 33.2 and $27.4 \mu \mathrm{m}$ thick, respectively. There are 3 vascular bundles. Length and width of the largest medium bundle are 177.4 and 218.5 $\mu \mathrm{m}$, respectively.

\subsubsection{Broccoli}

At the age of 30 days, Broccoli petiole is almost crescent shaped in transverse section (Fig., 5B), with dimensions of $584.1 \mu \mathrm{m}$ in length and $1168.2 \mu \mathrm{m}$ in width (Table, 4$)$. The upper epidermis is $21.7 \mu \mathrm{m}$ thick, while the lower one is $18.9 \mu \mathrm{m}$. Three vascular bundles are embedded in parenchymatous tissue. Length and width of the largest median bundle are 155.8 and $220.7 \mu \mathrm{m}$, respectively.

On the other hand, the petiole at the age of 45 days (Table, 5 and Fig., 6B) recorded $1224.6 \mu \mathrm{m}$ in length and $658.4 \mu \mathrm{m}$ in width. The upper and the lower epidermal cells are 35.5 and $28.4 \mu \mathrm{m}$. The vascular tissue consists of 3 bundles. The largest median bundle recorded 175.2 and $266.5 \mu \mathrm{m}$ in length and width, respectively.

\subsubsection{Cabbage}

The petiole of the first leaf, at the age of 30 days is almost kidney shaped (Fig., 5C), with a length and width of 877.5 and 1300.0 $\mu \mathrm{m}$, respectively. It has three vascular bundles embedded in the ground tissue. Dimensions of the largest median bundle are $162.5 \mu \mathrm{m}$ in length and $260.0 \mu \mathrm{m}$ in width (Table, 4).

The recorded measurements of the petiole at the age of 45 days are 912.7 and $574.2 \mu \mathrm{m}$ in length and width, respectively (Table, 5 and Fig., 6C). The upper and lower epidermis average 29.2 and $31.4 \mu \mathrm{m}$, respectively. There are 3 vascular bundles in the petiole. Length and width of the largest median bundle are 218.2 and $274.5 \mu \mathrm{m}$, respectively.

\subsubsection{The stem}

Stem anatomical structures of the three studied taxa are presented in Table 6 and Fig.7. 7.

\subsubsection{Cauliflower}

The stem is ovate in shape (Fig. 7A), $1293.4 \mu \mathrm{m}$ in diameter. Epidermis thickness is $15.5 \mu \mathrm{m}$. The cortex averages $220.7 \mu \mathrm{m}$ and consists of 7-9 layers. The stele consists of conjugated vascular bundles arranged in one ring. Vascular cylinder averages $129.8 \mu \mathrm{m}$ in thickness. Two major cortical bundles are located outside the vascular cylinder. The pith consists of round parenchyma cells $558.1 \mu \mathrm{m}$ in diameter and intercellular spaces of different sizes.

\subsubsection{Broccoli}

Stem in cross section is round, averaging 1022.1 $\mu \mathrm{m}$ in diameter, while the pith diameter is $415.4 \mu \mathrm{m}$ (Fig., 7B). The epidermis averages $17.1 \mu \mathrm{m}$, while cortex thickness is $155.8 \mu \mathrm{m}$, and consists of 6-8 layers. The vascular cylinder is $129.8 \mu \mathrm{m}$ thick, and consists of one ring of continuous bundles.

\subsubsection{Cabbage}

Cabbage stem is also round in outline, with diameter averages $1141.8 \mu \mathrm{m}$. Thickness of epidermis is $18.6 \mu \mathrm{m}$, while cortex (9-11 layers of parenchyma) is $155.8 \mu \mathrm{m}$ thick. Vascular cylinder averages $103.8 \mu \mathrm{m}$ in diameter and consists of one ring of correlated bundles. Pith diameter averages 584. $1 \mu \mathrm{m}$, ((Fig., 7C).

\subsubsection{The root}

Root anatomical features of the 10 day old seedlings of the three studied taxa are presented in Table (7) and Fig.8 (A, B and C).

\subsubsection{Cauliflower}

Structure of the main root as in (Fig., 8A); indicates irregular outline, with a diameter $312.2 \mu \mathrm{m}$. The epidermis thickness is $12.4 \mu \mathrm{m}$ and is ruptured in many parts due to the early start of secondary growth. The cortex is 90.9 $\mu \mathrm{m}$ thick with 3-4 layers. Vascular cylinder is $103.8 \mu \mathrm{m}$ in diameter. Number of primary xylem arms is four. At this age (10 days), there is no pith as the metaxylem occupies the center of the cross section, where the secondary growth starts early.

\subsubsection{Broccoli}

The root is slightly round in outline and its diameter is $452.3 \mu \mathrm{m}$ (Fig., 8B). The epidermis is $15.5 \mu \mathrm{m}$ thick and is ruptured in many parts. Thickness of cortex is $142.8 \mu \mathrm{m}$, with 4-5 layers. Diameter of vascular cylinder is $129.8 \mu \mathrm{m}$. The primary xylem consists of 
Table (4): Measurements of certain microscopical features in transverse sections of leaf petiole of 30 day old plant of the three studied taxa: Cauliflower, Broccoli and Cabbage. (Averages of 10 readings).

\begin{tabular}{|c|c|c|c|}
\hline Characters & Cauliflower & Broccoli & Cabbage \\
\hline Upper epidermis thickness $(\mu \mathrm{m})$ & 15.5 & 21.7 & 21.7 \\
\hline Lower epidermis thickness $(\mu \mathrm{m})$ & 9.3 & 18.9 & 15.5 \\
\hline \multicolumn{4}{|l|}{ Dimensions of the petiole $(\mu \mathrm{m})$ : } \\
\hline Length $(\mu \mathrm{m})$ & 780.0 & 584.1 & 877.5 \\
\hline Width $(\mu \mathrm{m})$ & 1365.0 & 1168.2 & 1300.0 \\
\hline No. of vascular bundles & 3.0 & 3.0 & 3.0 \\
\hline Length of median bundle $(\mu \mathrm{m})$ & 162.5 & 155.8 & 162.5 \\
\hline Width of median bundle $(\mu \mathrm{m})$ & 227.5 & 220.7 & 260.0 \\
\hline
\end{tabular}

Table (5): Measurements of certain microscopical features in transverse sections of leaf petiole of $\mathbf{4 5}$ day old plants of the three studied taxa; Cauliflower, Broccoli and cabbage. (Averages of 10 readings).

\begin{tabular}{|l|c|c|c|}
\hline \multicolumn{1}{r|}{ Taxa } & Cauliflower & Broccoli & Cabbage \\
Characters & & & \\
\hline Upper epidermis thickness $(\mu \mathrm{m})$ & 33.2 & 35.5 & 29.2 \\
\hline Lower epidermis thickness $(\mu \mathrm{m})$ & 27.4 & 28.4 & 31.4 \\
\hline Dimension of the petiole $(\mu \mathrm{m}):$ & & & \\
\hline \multicolumn{1}{|c|}{ Wength $(\mu \mathrm{m})$} & 694.8 & 1224.6 & 912.7 \\
\hline Width $(\mu \mathrm{m})$ & 487.3 & 658.4 & 574.2 \\
\hline No. of vascular bundles & 3.0 & 3.0 & 3.0 \\
\hline Length of median bundle $(\mu \mathrm{m})$ & 177.4 & 175.2 & 218.2 \\
\hline Width of median bundle $(\mu \mathrm{m})$ & 218.2 & 266.5 & 274.5 \\
\hline
\end{tabular}

Table (6): Measurements of certain microscopical features in transverse sections of the apical internode of 30 day old plants of the three studied taxa; Cauliflower, Broccoli and Cabbage. (Averages of 10 readings).

\begin{tabular}{|l|c|c|c|}
\hline \multicolumn{1}{|r|}{ Taxa } & Cauliflower & Broccoli & Cabbage \\
\hline Stem diameter $(\mu \mathrm{m})$ & & & \\
\hline Epidermis thickness $(\mu \mathrm{m})$ & 1293.4 & 1022.1 & 1141.8 \\
\hline Cortex thickness $(\mu \mathrm{m})$ & 15.5 & 17.1 & 18.6 \\
\hline No. of cortex layers & 220.7 & 155.8 & 155.8 \\
\hline Vascular cylinder thickness $(\mu \mathrm{m})$ & $7-9$ & $6-8$ & $9-11$ \\
\hline Pith diameter $(\mu \mathrm{m})$ & 129.8 & 129.8 & 103.8 \\
\hline
\end{tabular}

Table (7): Measurements of certain microscopical features in transverse sections of the root of 10 day old plants of the three studied taxa; Cauliflower, Broccoli and Cabbage (Averages of 10 readings).

\begin{tabular}{|c|c|c|c|}
\hline Taxa & Cauliflower & Broccoli & Cabbage \\
\hline Root diameter $(\mu \mathrm{m})$ & 312.2 & 452.3 & 389.4 \\
\hline Epidermis thickness $(\mu \mathrm{m})$ & 12.4 & 15.5 & 12.4 \\
\hline Cortex thickness $(\mu \mathrm{m})$ & 90.9 & 142.8 & 129.8 \\
\hline No. of cortex layers & $3-4$ & $4-5$ & $4-5$ \\
\hline Vascular cylinder diameter $(\mu \mathrm{m})$ & 103.8 & 129.8 & 103.8 \\
\hline No. of xylem arms & 4.0 & 4.0 & 4.0 \\
\hline
\end{tabular}



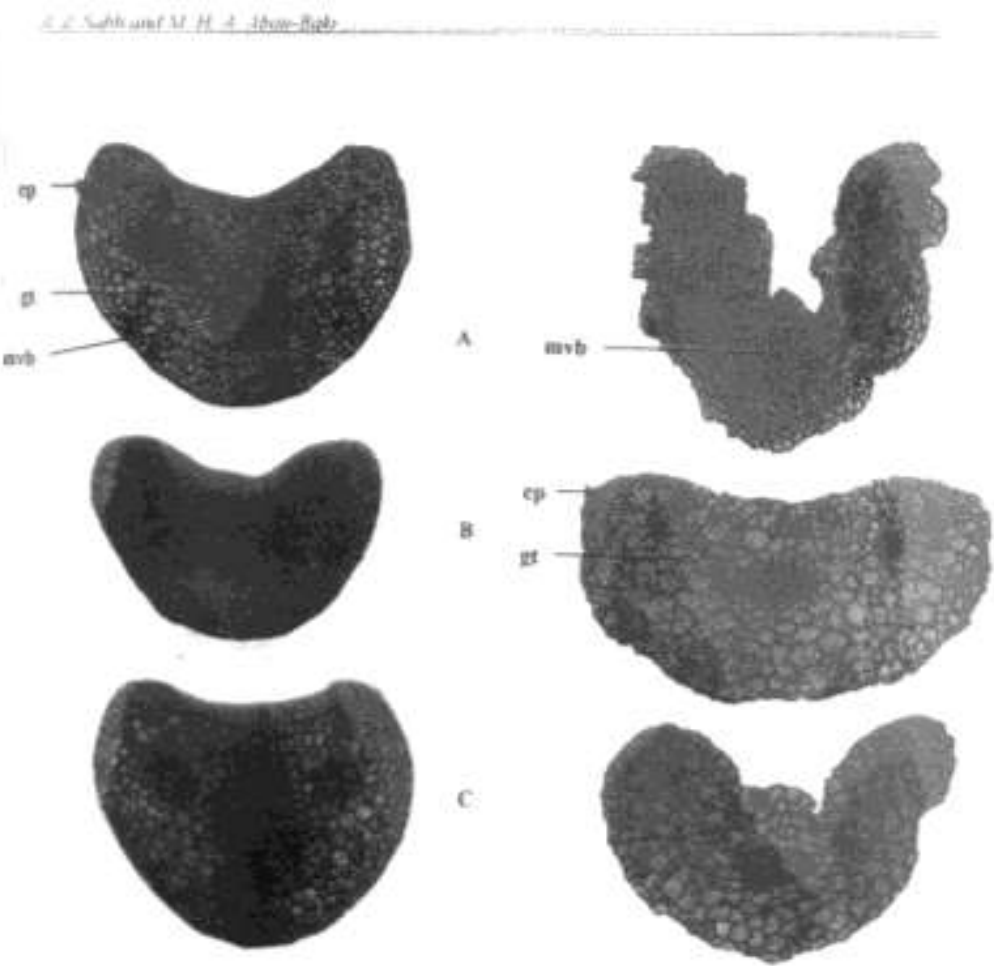

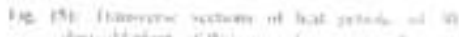

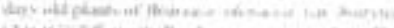

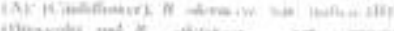

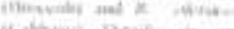

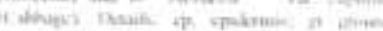

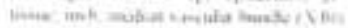

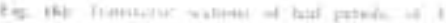

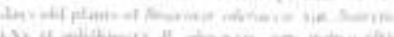

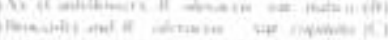

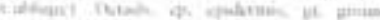

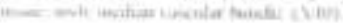

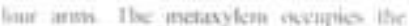

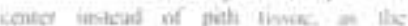
weondang powith stanch

$3.2+.3$ C ahhags

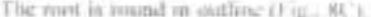

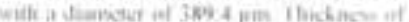

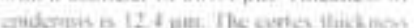

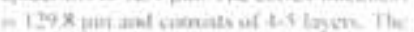

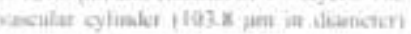

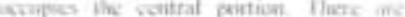

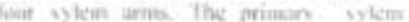

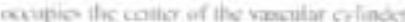
dow ay the ewh sarfine al scividur yeinet

19.2 .5 seed serface sculpturv sharacien

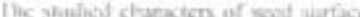

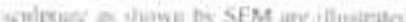
in Platc I if mal on Seat merfage

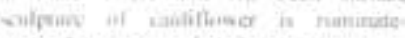

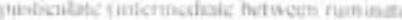

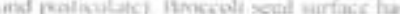

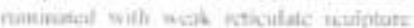




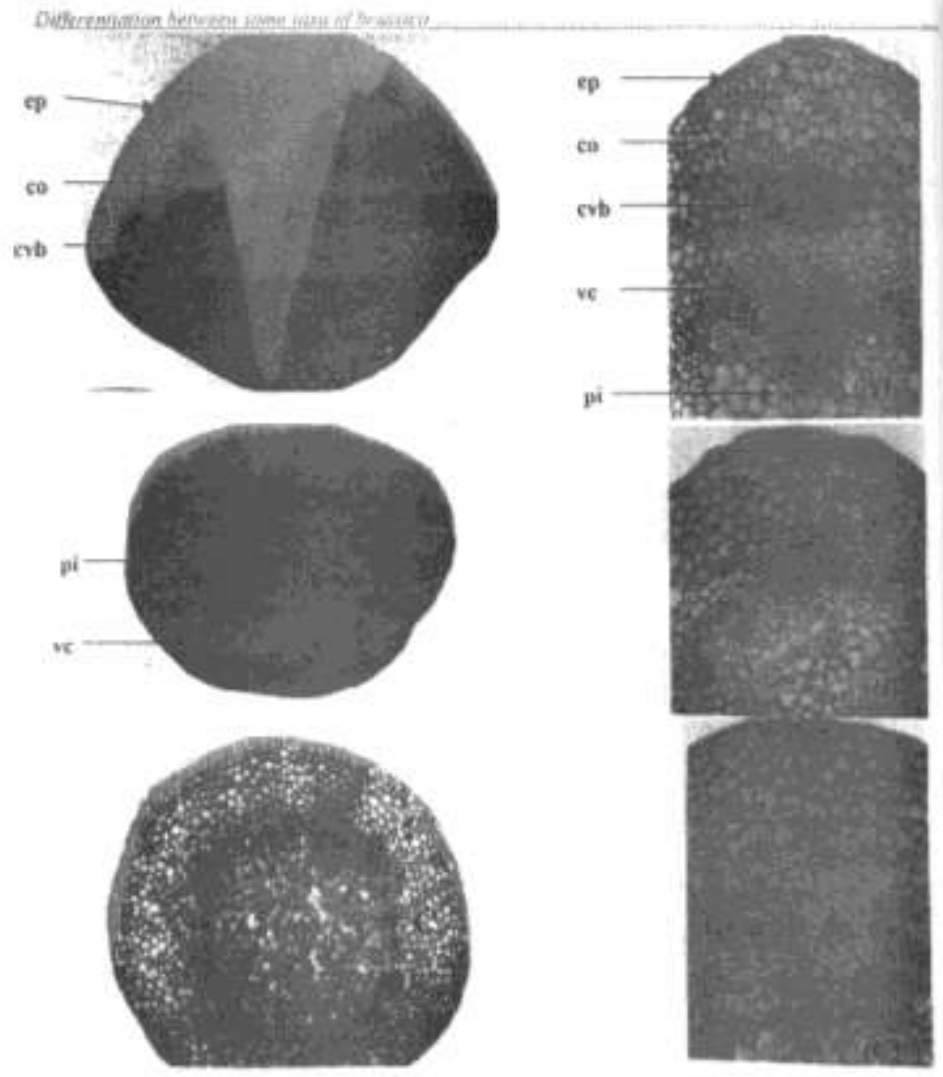

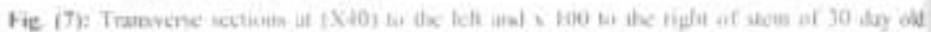

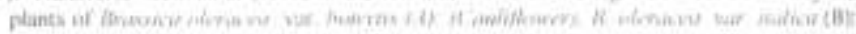

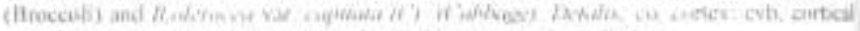

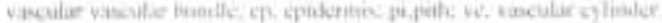

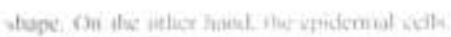

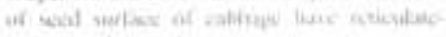

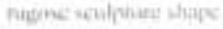

\section{Comalusians}

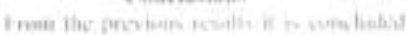

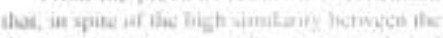

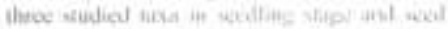

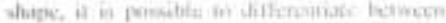

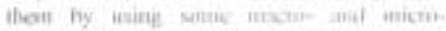

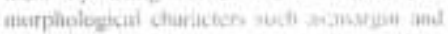

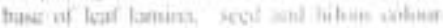

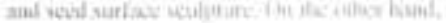

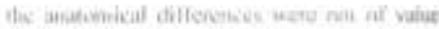

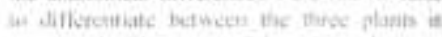

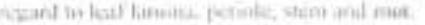

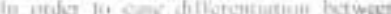

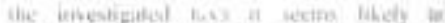

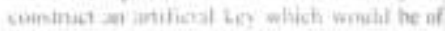
valoc in this roper

i tear ig nebuine

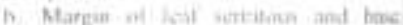

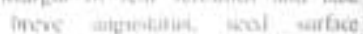

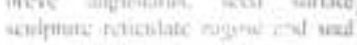

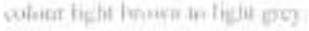
15, thithaye) 


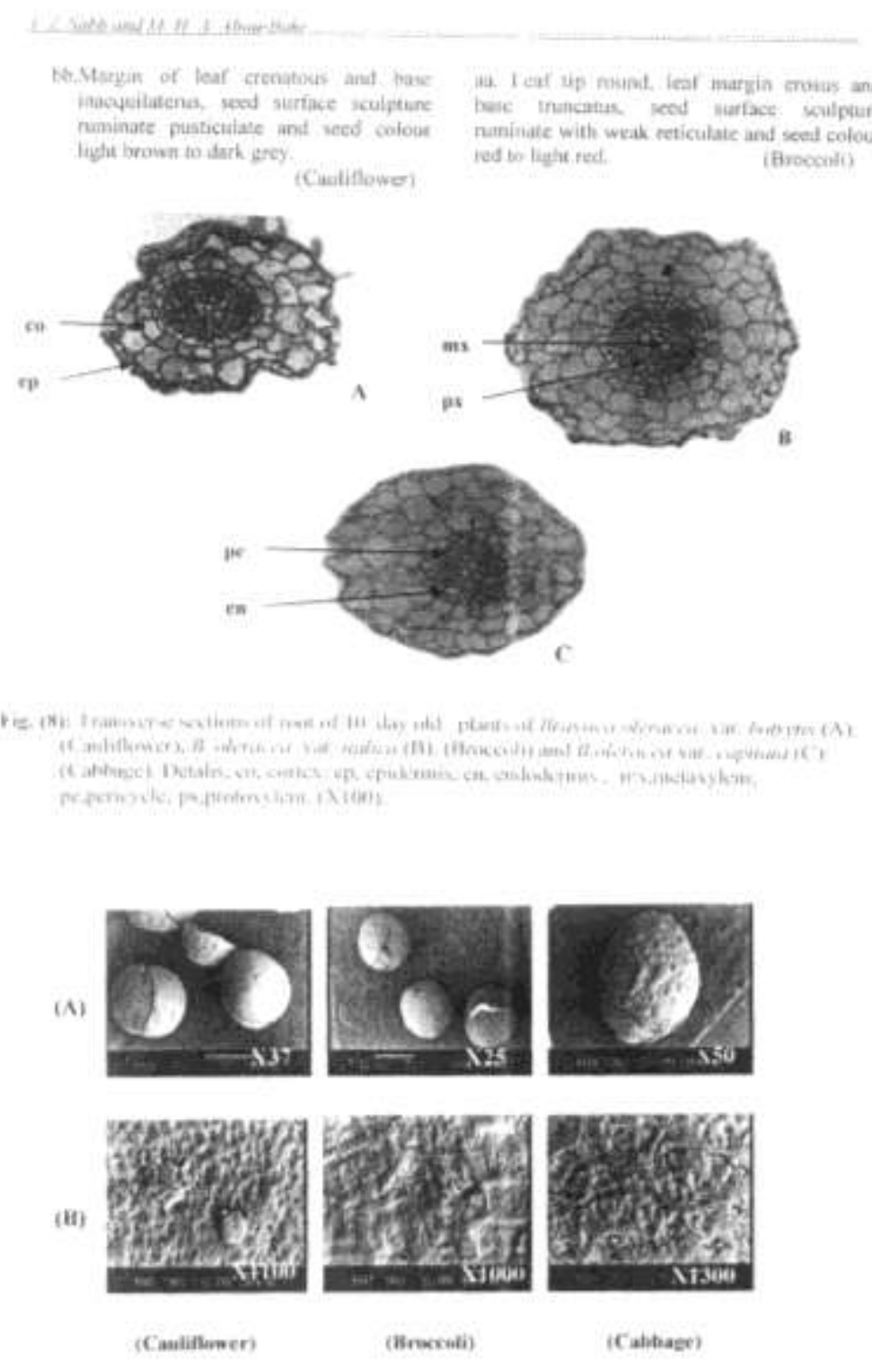

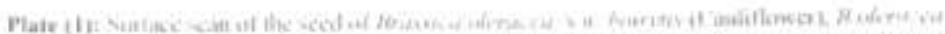

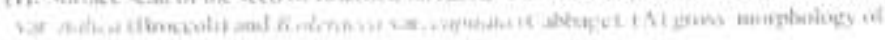

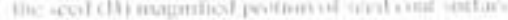




\section{REFERENCES}

Cronquist, A. (1981). An Integrated System of Classification of Flowering Plants.Columbia University Press, N.Y. p. 446-449.

Downey, R. K. (1990). Brassica oilseed breeding: Achievements and opportunities. Plant Breeding Abstracts, 1165-1170.

Jackson, G. (1926). Crystal violet and erythrosin in plant anatomy. Stain Tech., 1: 33-34.

Jones, S.B. and Luchsinger, A.E. (1987). Plant Systematic. $2^{\text {nd }}$ Edit. McGraw-Hill Book. Co., N.Y. p. 342-344.

Karcz, J.; Ksiazczyk, T. and Maluszynska, J. (2005). Seed coat patterns in RapidCycling Brassica forms. Acta Biologica Cracoviensia Series Botanica 47/1: 159165.

Koul K.K., Ranjna N. and Raina, S.N. (2000). Seed coat micro-sculpturing in Brassica and allied genera ( subtribes Brassicinae, Raphaninae, Moricandiiae). Annals of Botany 86:85-397.

Kumar D. (1995). Salt tolerance in oilseed Brassicas: Present status and future prospects, Plant Breeding Abstracts, 65:1438-1447.
Murley M. R. (1951). Seeds of the Cruciferae of Northeastern North America. American Mid. Nat., 46: 1-81.

Robbelen G., Downey R.K. and Ashri, A. (1989). Oil Crops of the World. Their Breeding and Utilization. McGraw-Hill Book Co., N.Y. 553 pp.

Sass, J. F. (1958). Botanical Microtechnique. Iowa State College Press, Ames, Iowa, 228. pp.

Stearn W.T. (1983). Botanical Latin. $3^{\text {rd }}$ Edit. David \& Charles Inc. USA. 553 pp.

Tantawy, M. E.; Khalifa, S. F.; Hassan, S. A. and Al-Rabiai, G.T. (2004). Seed exomorphic characters of some Brassicaceae (LM and SEM study). Int. J. Agri. Biol. 6 (5): 821-830.

Vaughan J.G. and Whitehouse, J.M. (1971). Seed structure and the taxonomy of the Cruciferae. Bot. J. Linn. Soc.,64:3.

Willis J.C. (1973). A Dictionary of the Flowering Plants and Ferns. $8^{\text {th }}$ Edit. Cambridge University Press, Cambridge et alibi. 1245 pp.

Zeng C. L.,Wang J.B., Liu A. H. and Wu X.M. (2004). Seed coat microsculpturing changes during seed development in diploid and amphidiploid Brassica species. Annals of Botany 93:555-566.

\footnotetext{
التمييز بين بعض الفئات التصنيفية التابعة لجنس Brassica و المتثابهة فى شكل البذرة والأعضاء النباتية في المراحل المبكرة للنمو

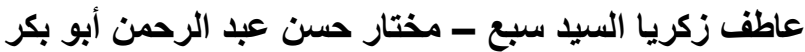$$
\text { قسم النبات الزراعى ـ كلية الزر اعة ـ جامعة القاهرة - الجيزة }
$$

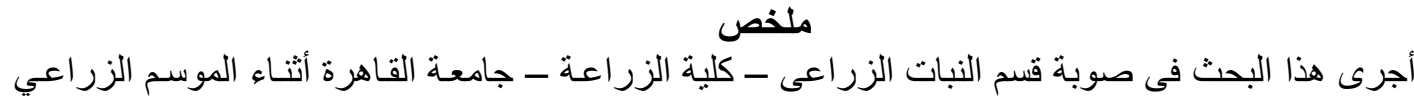$$
2006 \text { بهدف توضيح الاختلافات بين ثلاث فئات تصنيفية من جنس Brassica }
$$$$
\text { أولآ: (نleracea var. botrytis L. (Cauliflower) }
$$$$
\text { B.oleracea var. italica L (Broccoli) ثانيا: }
$$$$
\text { B.oleracea var capitata L. (Cabbage) ثأثالا: }
$$

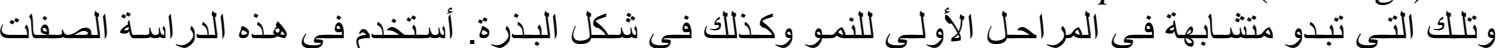

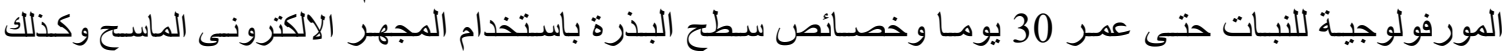

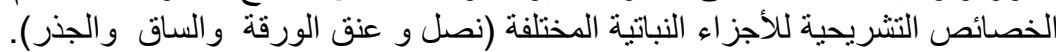

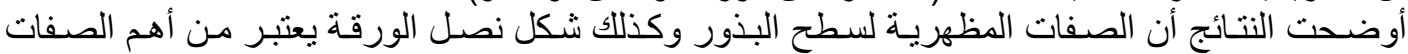

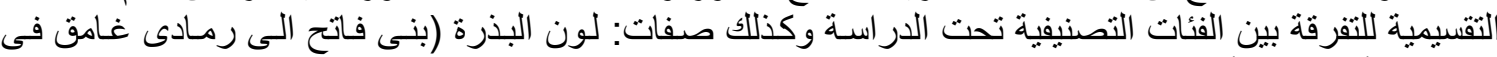

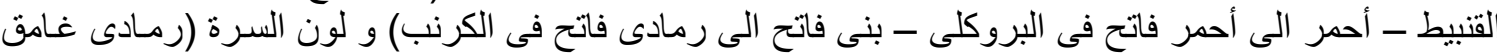


فى القنبط - بنى فاتح فى البروكلى - رمادى فاتح فى الكرنب) و المستح السطحى للبذور وحافة وقاعدة نصل

ومن ناحية أخرى كانت الاختلافات التشريحية للأجز اء النباتية بين الفئات التصنيفيه الثلاثة في المر احل الورقة.

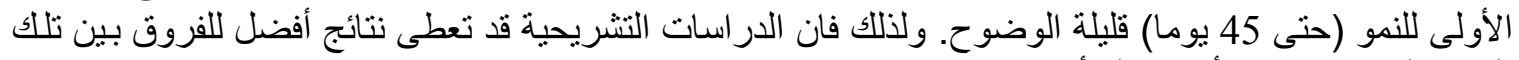
الفئات التصنيفية فى الأعمار المتأخرة. المجلة العلمية لكلية الزراعة - جامعة القاهرة - المجلا (60) العدد الأول (يناير 2009):42-31 . 